\title{
THE RETRANSLOCATION OF BORON IS INFLUENCED BY THE NUTRITIONAL STATUS OF CHERRY TOMATO PLANTS
}

\author{
A RETRANSLOCAÇÃO DE BORO É INFLUENCIADA PELO STATUS \\ NUTRICIONAL EM PLANTAS DE TOMATE CEREJA
}

\author{
Denison Queiroz POGORZELSKI ${ }^{1}$; Daniel Teixeira PINHEIRO ${ }^{2, *}$; Vanessa de QUEIROZ ${ }^{2}$; \\ Jaqueline do Carmo ALEXANDRE ${ }^{2}$; Arlindo Ferreira de FARIA ${ }^{1}$; \\ Herminia Emilia Prieto MARTINEZ ${ }^{2}$ \\ 1. Universidade Federal de Viçosa, Campus Viçosa, Departamento de Solos e Nutrição de Plantas, Viçosa, MG, Brasil. \\ denison.po.gorzelski@hotmail.com; 2. Universidade Federal de Viçosa, Campus Viçosa, Departamento de Fitotecnia, Viçosa, MG, \\ Brasil.pinheiroagroufv@gmail.com*.
}

\begin{abstract}
Boron (B) retranslocation may confer greater tolerance to B deficiency or toxicity, resulting in plants and fruits with better nutritional quality. Most plants do not demonstrate phloem mobility for $\mathrm{B}$; however, some plants have natural mobility and others express it under stress conditions, such as nutritional stress. Therefore, we investigated the phloem mobility of B in cherry tomato plants with different nutritional status. The plants were cultivated in nutrient solution with adequate and insufficient doses of Potassium (K) and B. Furthermore, the plants received foliar fertilization with B in a mature leaf $(F)$ in a localized form. The B content and amount in leaves near $\mathrm{F}$ were compared with leaves of the same age and position on control plants. The experiment was carried out in a protected environment and conducted in a randomized complete block design in a subdivided plot scheme with four replicates. Re-translocation of B between neighboring leaves was observed when the plant was without K deficiency and with B deficiency. In this nutritional status, leaves next to fertilized leaf with B (F) showed higher B amount when compared to leaves of the same position of control plants. Evidence suggests that retranslocation of B over relatively short distances (between leaves) can be influenced by the nutritional status the cherry tomato plants.
\end{abstract}

KEYWORDS: Solanum lycopersicum L. var. cerasiforme. Phloem mobility. Potassium.

\section{INTRODUCTION}

Boron (B) is an essential element in higher plants, and among its various functions, cell walls formation, sugar transport, plasma membrane stability among others still not well known are stand out (CAKMAK; RÖMHELD, 1997; TANAKA; FUJIWARA 2008; REID, 2014).

Reid (2014) states because cells depend on cell wall structure, B must be efficiently distributed in all plant tissues. In this context, the translocation of this element may confer better tolerance to deficiency or toxicity (BROWN; SHELP, 1997). However, depending on the species, it is considered a low mobile or immobile element in phloem (VAN GOOR; LUNE, 1980; BROWN; SHELP, 1997). In summary, B translocation involves active efflux channels and pumps with specific expression patterns depending on internal and external factors (LEAUNGTHITIKANCHANA et al. 2013).

In addition to being an essential element, potassium $(\mathrm{K})$ is also mentioned because of its relationship with $\mathrm{B}$, as its deficiency can reduce the photosynthesis (PEOPLES; KOCH, 1979) and affect the export capacity of sucrose in phloem (HU et al. 2017). Keller and Shrestha (2014) reinforce this information by finding a positive correlation between sugars present in the vacuole and the $\mathrm{K}^{+}$ concentrations, indicating an influx of sugar and potassium coupled through the phloem. Furthermore, Samet, Cikili and Dursun (2015) observed that the addition of $\mathrm{K}$ not only attenuated the inhibitory effect of excess $\mathrm{B}$ in pepper plants, but also decreased leaf amount and promoted a higher balance of other nutrients.

Tomato (Solanum lycopersicum L.) is one of the main vegetables produced in the world and among the different groups, cherry (S. lycopersicum var. cerasiforme) has the main characteristics of good productivity and higher concentration of soluble solids when compared to other groups (PÉK et al., 2014; SANTIAGO et al., 2018). Recent studies have shown the effect of B on cherry tomatoes, such as increased shelf life and vitamin C content (ISLAM et al., 2016; ISLAM et al., 2018). However, there are few studies that relate the transport mechanisms of $\mathrm{B}$ related to $\mathrm{K}$ content and nutritional status as a whole.

In view of the above, the aim of this study was to evaluate the phloem mobility of B in cherry 
The retranslocation...

tomato plants and, mainly, to investigate B mobility according to the nutritional status of $\mathrm{K}$ and $\mathrm{B}$.

\section{MATERIAL AND METHODS}

The experiment was carried out in the Plant Science Department of the Universidade Federal de Viçosa, Brazil (20 45' 37" S 42 52' 04" W, 648 m altitude) between the 2015 and 2016 years.

Initially, seedlings of cherry tomatoes (Topseed Garden $\AA$, Blue Line, not hybrid) were produced by sowing in phenolic foam. After 21 days, the seedlings were transferred to $16 \mathrm{~L}$ pots containing nutrient solution. A modified nutrient solution by Hoagland and Arnon (1950) was used, with combinations between two doses of $\mathrm{K}$ ( 1 and 6 mmol L $\left.{ }^{-1}\right)$ and two doses of $\mathrm{B}(<3$ and $46 \mu \mathrm{mol} \mathrm{L}$ $\left.{ }^{1}\right)$, constituting the treatments $\mathrm{K}-\mathrm{B}-; \mathrm{K}-\mathrm{B}+$; $\mathrm{K}+\mathrm{B}-$; $\mathrm{K}+\mathrm{B}+$. Two plants were maintained per pot and the

\section{POGORZELSKI et al.}

$\mathrm{pH}$ solution of all treatments was maintained between 5.5-6.0 by application of $\mathrm{HCl}$ (1M) or $\mathrm{NaOH}(1 \mathrm{M})$, when necessary.

After 40 days of cultivation, the first fully expanded leaf, counted from the apex, received on both sides the volume of $400 \mu \mathrm{L}$ of boric acid solution $\left(0.340 \mathrm{~g} \mathrm{~L}^{-1} \mathrm{H}_{3} \mathrm{BO}_{3}\right)$ (GONDIM et al. 2015). The localized foliar fertilization was carried out with the aid of a micropipette and an anti-drip brush.

The evaluation of the phloem mobility of $B$ was carried out by comparing the B content and amount of the neighboring leaves, immediately above and below the fertilized leaf (F) with $\mathrm{H}_{3} \mathrm{BO}_{3}$ (Figure 1b) in relation to leaves of the same age and position of control plants (Figure 1a). The evaluated leaves were called indicator leaves and numbered 1 and 3 in the control plants and 2 and 4 in the plants that received application of $\mathrm{B}$ via foliar (Figure 1).

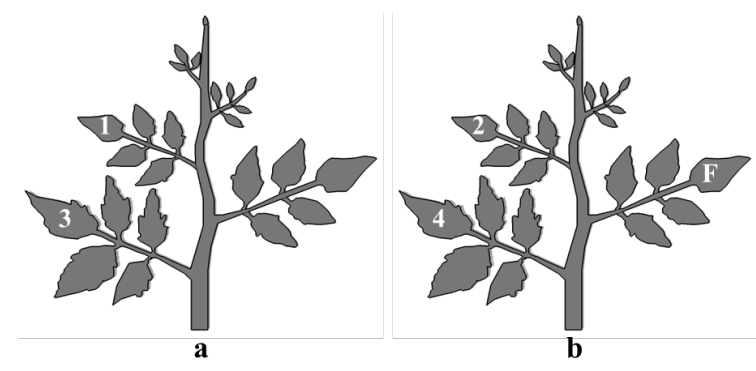

Figure 1. Schematic representation of the control plant (without foliar application of B) (a) plant that received foliar fertilization of B (b).

Young leaf of the control plant (1); Young leaf of the plant fertilized with B (2); Mature leaf of control plant (3); Mature leaf fertilized with B (4); Fertilized leaf with B (F).

After $24 \mathrm{~h}$ of foliar application of $\mathrm{B}$, the leaves of all indicated positions were harvested, calcined and subjected to acid digestion with $\mathrm{HCl}$. Then, B (azomethine-H) and K (flame photometer) were dosed into the plant tissue as described by (SILVA, 2009).

Although the B in the fertilized leaves with B (F) was measured, their amount was not included in the descriptive and inferential statistics. They were shown for informational purposes only, since the $\mathrm{B}$ of leaf $\mathrm{F}$ may have been the result of retention of the element on the leaf surface or in the cuticle, not representing B effectively absorbed by the leaf.

The experiment was conducted in a randomized complete block design (CBD) in subdivided plots. The nutritional status constituted in the plots and the indicator leaves in the subplots. Four replicates were used per treatment.

The response variables were the $\mathrm{K}$ and $\mathrm{B}$ content and amount in the indicator leaves (Figure 1). The amount was obtained by multiplying the nutrient content by the dry matter mass of the sampled leaf.

Variance analysis (ANOVA) was performed without data transformation, provided that the response variables showed normal distribution (Kolmogorov-Smirnov, $\alpha=5 \%$ ) or homogeneity of variances (Levene, $\alpha=5 \%$ ). The means were compared by the Scott-Knott test $(\mathrm{p} \leq 0.05)$, in order to avoid overlapping groups of means. Statistical analyses were carried out in software R.

\section{RESULTS AND DISCUSSION}

As expected the B amount in the cherry tomato leaves was higher in the treated plants with the presence of $\mathrm{B}(\mathrm{K}-\mathrm{B}+$ and $\mathrm{K}+\mathrm{B}+)$, with means of 0.17 and $0.26 \mathrm{mg} \mathrm{leaf}^{1}$, respectively. However, in the $\mathrm{K}+\mathrm{B}+$ treatment this value was higher, indicating that the presence of $\mathrm{K}$ positively affects the B amount (Figure 2A). 


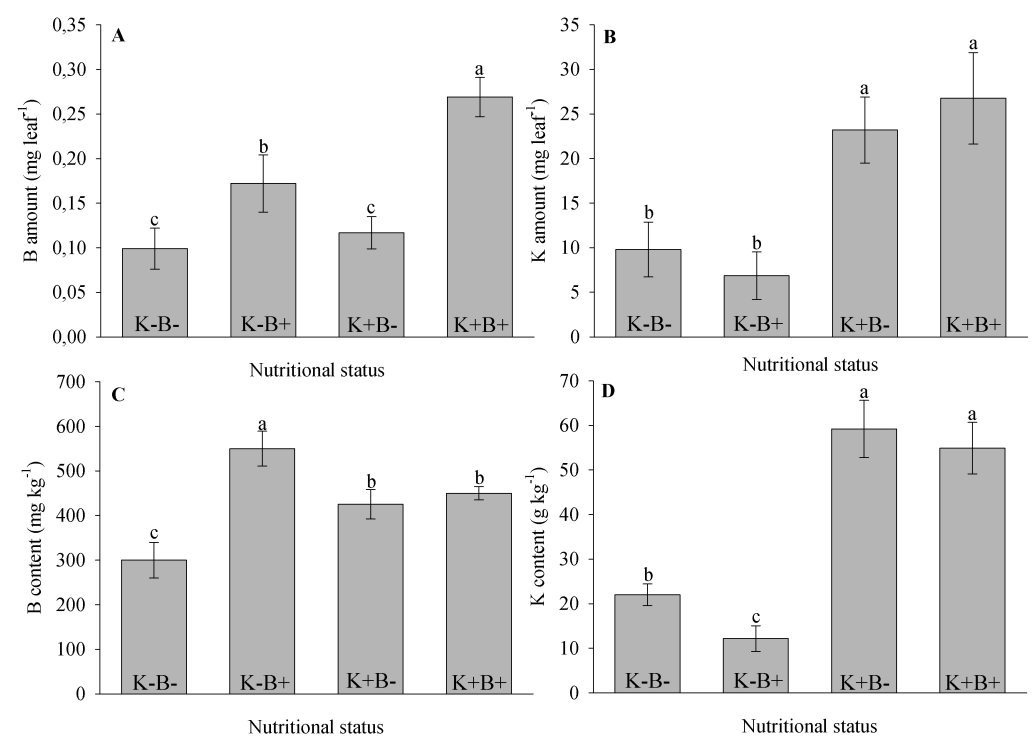

Figure 2. Simple effects of nutritional status (K-B-; K-B+; K+B-; K+B+) in $B(A$ and $C)$ and $K(B$ and $D)$ content and amount in cherry tomato leaves.

Means followed by the same letter do not differ statistically from each other at $5 \%$ of probability by the Scott-Knott test. (Bars: standard error).

Considering the $\mathrm{B}$ content, an average value of $427 \mathrm{mg} \mathrm{kg}^{-1}$ was observed, being higher in the $\mathrm{K}$ $\mathrm{B}+$ treatment (Figure 2C). The mean B content was higher than that observed in the conventional tomato (209 $\mathrm{mg} \mathrm{kg}^{-1}$ ) (FERNANDES et al., 2002) and cherry tomato cultivated in different substrates (115 $\mathrm{mg} \mathrm{kg}{ }^{-1}$ ) (FERNANDES; CORÁ; BRAZ, 2006). This result may have been due to the characteristics of the cultivar and the hydroponic cultivation system used.

Although, it was observed a higher $\mathrm{B}$ amount in $\mathrm{K}+\mathrm{B}+$ treatment (Figure $2 \mathrm{~A}$ ), the content was higher in $\mathrm{K}-\mathrm{B}+$ (Figure 2C). That is related a higher $\mathrm{B}$ concentration per unit mass of the sampled plant tissue, due to the reduced plant growth (concentration effect), which is related to $\mathrm{K}$ deficiency. In this context, the use of the variable amount was more adequate compared to content. It is worth noting that concentration or dilution effect can induce misunderstandings in the interpretation of B mobility between leaves, especially when there are factors under study that drastically influence the development of plants, such as nutritional or climatic factors.

Relative to $\mathrm{K}$, were observed mean values of amount and content of $16.7 \mathrm{mg}$ leaf $^{1}$ and $36.9 \mathrm{~g}$ $\mathrm{kg}^{-1}$, respectively. The $\mathrm{K}$ content and amount provided similar information (Figures $2 \mathrm{~B}$ and $2 \mathrm{D}$ ). Plants cultivated with inadequate doses of $\mathrm{B}$ and $\mathrm{K}$ showed deficiency symptoms for both nutrients (data not shown). The observed symptoms are in accordance with those described by Malavolta (2006), such as the shading and chlorosis in apical leaves of B deficient plants and reduced vegetative growth and necrosis at the edges of the basal leaves in $\mathrm{K}$ deficient plants.

In general, the results for the amount for both nutrients are in agreement with the expected, evidencing the presence of different populations of plants (different status of $\mathrm{K}$ or B), which allows the interaction study. The ANOVA showed that there are significant differences for the $\mathrm{B}$ and $\mathrm{K}$ content and amount $(\mathrm{p} \leq 0.00)$, in the different nutritional status (K-B-; K-B+; K+B-; $\mathrm{K}+\mathrm{B}+$ ) (Table 1).

The $\mathrm{B}$ mobility can be easily verified by the difference in the $\mathrm{B}$ amount or content between mature and young leaves (MINCHIN et al., 2012; HAJIBOLAND et al., 2013). In this study, B mobility as a function of the nutritional status of the plants can be verified by means of the interaction effect, which was significant among the indicator leaves within the nutritional status of the plant (Table 1).

By means of the Scott-Knott test, it could be seen that in the $\mathrm{K}+\mathrm{B}$ - treatment the mature (3) and young (1) leaves of the control plants presented lower amount (Figure 3A) and content (Figure 3B) of $\mathrm{B}$ when compared to mature (4) and young (2) leaves neighboring $\mathrm{F}$ (fertilized leaf with $\mathrm{B}$ ).

This result indicates that cherry tomato plants retranslocated $\mathrm{B}$ in the presence of adequate $\mathrm{K}$ and inadequate $\mathrm{B}$ amounts. Furthermore, it can be seen that $B$ retranslocation occurred in both directions (above and below) in relation to $\mathrm{F}$ leaf (Figure 3). In general, nutrient retranslocation is known to be enhanced under deficient conditions. 
According to Eggert and von Wirén (2017), nutritional status B causes coordinated changes in plant hormone metabolism as a prerequisite for an adjusted growth response. In this context, it was observed that B influenced the nutritional status and nutritional efficiency in pepper plants, with different responses depending on genotype, B concentration and the nutrient (SARAFI et al., 2018). Thus, B deficiency in $\mathrm{K}+\mathrm{B}$ - treatment could have promoted the retranslocation in cherry tomato plants as a physiological response, such as observed in radish plants (TARIQ; MOTT, 2006). In soybean plants cultivated at different concentrations of ${ }^{11} \mathrm{~B}(0,10$, 30 and $100 \mu \mathrm{M}$ ) the ${ }^{10} \mathrm{~B}$ retranslocation (foliar application) among the leaflets was higher in plants grown at $0 \mu \mathrm{M}$ of ${ }^{11} \mathrm{~B}$ (WILL et al., 2011).

Table 1. Summary of the variance analysis ( $p$-value) of B and $\mathrm{K}$ content in indicator ${ }^{2}$ leaves of cherry tomato cultivated in different nutritional ${ }^{1}$ status for 41 days in hydroponic system.

\begin{tabular}{lllll}
\hline Source of variation & Content & \multicolumn{3}{l}{ Amount } \\
\hline & $\mathrm{B}$ & $\mathrm{K}$ & $\mathrm{B}$ & $\mathrm{K}$ \\
\hline${ }^{\mathrm{I}}$ Nutritional status & $<0.001^{* * *}$ & $<0.001^{* * *}$ & $<0.001^{* * *}$ & $<0.001^{* * *}$ \\
${ }^{2}$ Indicator leaves & 0.89 & 0.46 & 0.059 & 0.51 \\
Nut. status $\times$ Ind. leaves & $0.0016^{*}$ & 0.057 & $0.03^{*}$ & 0.59 \\
Ind. leaves/K-B- & 0.057 & - & 0.54 & - \\
Ind. leaves/K-B+ & 0.096 & - & $0.0139^{*}$ & - \\
Ind. leaves/K+B- & $0.0011^{*}$ & - & $0.0141^{*}$ & - \\
Ind. leaves/K+B+ & 0.89 & - & 0.36 & - \\
\hline
\end{tabular}

${ }^{1}$ Nutritional status (K-B-; K-B+; K+B-; K+B+). ${ }^{2}$ Indicator leaves $(1 ; 2 ; 3 ; 4$; see Figure 1$) .{ }^{* * *}$ significant at level of $0.1 \%$ of probability $(p \leq 0.001),{ }^{*}$ significant at level of $5 \%$ of probability $(0.01<p \leq 0.05)$.

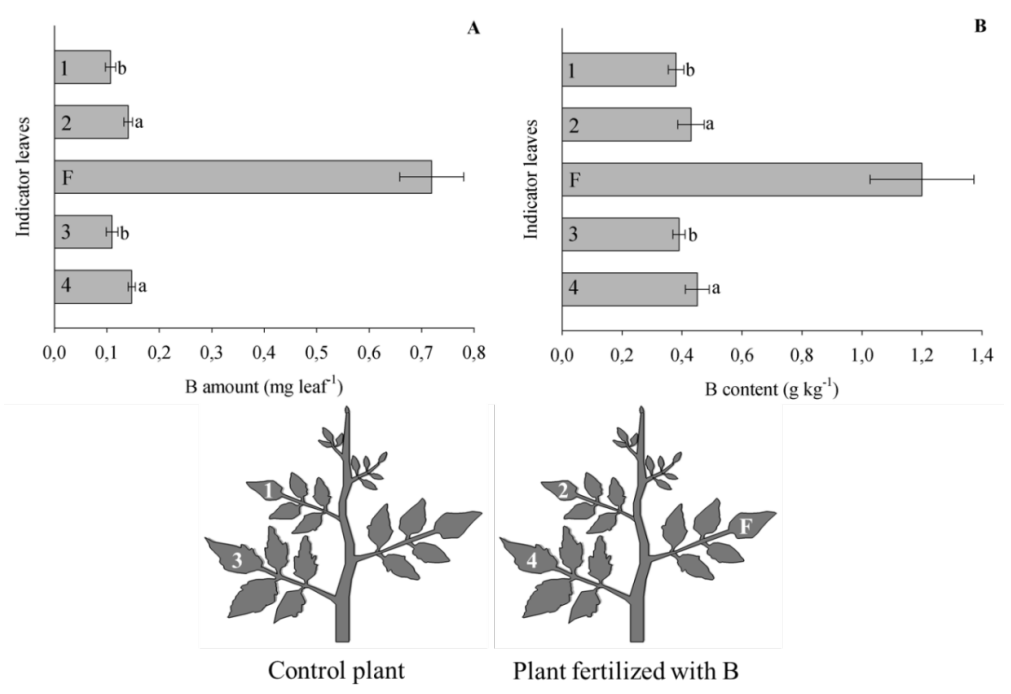

Figure 3. B amount and content in cherry tomato leaves of unfertilized plants and those fertilized with B.

Young leaf of the control plant (1); Young leaf of the plant fertilized with B (2); Mature leaf of control plant (3); Mature leaf fertilized with B (4); Leaf that received application B (F). Means followed by the same letter do not differ statistically from each other at $5 \%$ of probability by the Scott-Knott test (Bars: standard error).

The nutritional status of $\mathrm{K}$ in the plant also influences the transport capacity of the phloem. Saccharose and $\mathrm{K}^{+}$ions are the main constituents of the phloem solution, acting together to maintain osmotic potential. Thus, the discharge of these solutes into the phloem decreases its osmotic potential and favors the formation of the hydrostatic pressure gradient between the source and the drain, generating the transport flux in this tissue (TAIZ et al., 2017).

However, the B transport in plants also involves other nutrients and compounds. As an example, the investigation of the phloem solution in some translocating species of B revealed substantial levels of polyols, which are able to form complexes with B (B-polyol) and promote the phloem transport of $\mathrm{B}$ over relatively long distances in plants 
The retranslocation...

(BROWN; SHELP, 1997; SOUZA; CANESIN; BUZETTI, 2012). However, in this work the phloem solution of the cherry tomato was not characterized and, therefore, it is not possible to affirm whether the nutritional status in $\mathrm{K}$ influenced the synthesis of polyols.

There is little evidence in the literature about B retranslocation capacity in plants of the Solanaceae family, such as tomatoes. Through genetic manipulation, Brown et al. (1999) introduced complementary DNA (cDNA) in tobacco plants (Solanaceae, Nicotianatabacum L.) and the plants started to synthesize the polyol sorbitol (sorbitol-6-phosphate dehydrogenase). The plants showed B phloem mobility and did not show symptoms of deficiency of this element, even when subject to inadequate supply of B. On the other hand, control (non-transgenic) plants showed symptoms of B deficiency, evidencing the null or reduced capacity of this species to retranslocate this element, which may be a possible intrinsic feature of Solanaceae's family. However, this work evidenced the retranslocation of $\mathrm{B}$ between neighboring leaves in cherry tomatoes, occurring in

\section{POGORZELSKI et al.}

a timely way when the plant was at adequate $\mathrm{K}$ and inadequate $\mathrm{B}$ levels.

\section{CONCLUSION}

The nutritional status of $\mathrm{K}$ influences $\mathrm{B}$ retranslocation in cherry tomato plants over relatively short distances. Further studies are needed to show that retranslocation occurs at relatively large distances, attending drainage regions distant from the fertilized leaf, such as the roots and fruits.

\section{ACKNOWLEDGEMENTS}

This study was financied in part by the Coordenação de Aperfeiçoamento de Nível Superior - Brasil (CAPES) (Finance Code: 001), Conselho Nacional de Desenvolvimento Científico e Tecnológico (CNPq) and Fundação de Amparo à Pesquisa do Estado de Minas Gerais (FAPEMIG). The authors also would like to thank the Plant and Soil Science Departments of Universidade Federal de Viçosa (UFV) for the infrastructure offered.

RESUMO: A retranslocação de Boro (B) pode conferir maior tolerância à deficiência ou toxidez de B, resultando em plantas e frutos com melhor qualidade nutricional. A maioria das plantas não demonstra mobilidade floemática para o $\mathrm{B}$, contudo, algumas plantas possuem mobilidade natural e outras a expressam sob condições de estresse, como o estresse nutricional. Nesse sentido, foi investigada a mobilidade floemática do B em plantas de tomate cereja com diferentes status nutricionais. As plantas foram cultivadas em solução nutritiva com doses adequada e insuficiente de Potássio (K) e B. Adicionalmente, as plantas receberam, de forma localizada, fertilização foliar com B em uma folha madura (F). Os teores e os conteúdos de B nas folhas vizinhas a $\mathrm{F}$ foram comparados com folhas de mesma idade e posição de plantas controle. $\mathrm{O}$ experimento foi realizado em ambiente protegido e conduzido no delineamento de blocos casualizados em esquema de parcelas subdivididas com quatro repetições. Evidenciou-se retranslocação de B entre folhas vizinhas quando a planta estava sem deficiência de $\mathrm{K}$ e com deficiência de B. Neste status nutricional, as folhas vizinhas à folha aplicada (F) apresentaram maiores teores e conteúdos de $\mathrm{B}$ quando comparadas às folhas de mesma posição das plantas controle. As evidências sugerem que a retranslocação de B em distâncias relativamente curtas (entre folhas) pode ser influenciada pelo status nutricional de plantas de tomate cereja.

PALAVRAS-CHAVE: Solanum lycopersicum L. var. cerasiforme. Mobilidade floemática. Potássio.

\section{REFERENCES}

BROWN, P. H.; SHELP, B. J. Boron mobility in plants. Plant and Soil, v. 193, n. 2, p. 85-101, 1997. https://doi.org/10.1023/A:1004211925160

BROWN, P. H.; BELLALOUI, N., HU, H.; DANDEKAR, A. Transgenically enhanced sorbitol synthesis facilitates phloem boron transport and increases tolerance of tobacco to boron deficiency. Plant physiology, v. 119, n. 1, p. 17-20, 1999. https://doi.org/10.1104/pp.119.1.17

CAKMAK, I.; RÖMHELD, V. Boron deficiency-induced impairments of cellular functions in plants. Plant and Soil, v. 193, n. 2, p. 71-83, 1997. https://doi.org/10.1023/A:1004259808322 
EGGERT, K.; VON WIRÉN, N. Response of the plant hormone network to boron deficiency. New Phytologist, v. 216, n. 3, p. 868-881, 2017. https://doi.org/10.1111/nph.14731

FERNANDES, A. A.; MARTINEZ, H. E. P.; FONTES, P. C. R. Produtividade, qualidade dos frutos e estado nutricional do tomateiro tipo longa vida conduzido com um cacho, em cultivo hidropônico, em função das fontes de nutrientes. Horticultura Brasileira, v. 20, n. 4, p. 564-570, 2002. https://doi.org/10.1590/S010205362002000400011

FERNANDES, C.; CORÁ, J. E.; BRAZ, L. T. Desempenho de substratos no cultivo do tomateiro do grupo cereja. Horticultura Brasileira, v. 24, n. 1, p. 42-46, 2006. https://doi.org/10.1590/S010205362006000100009

GONDIM, A. R. O.; MELLO PRADO, R.; CECÍLIO FILHO, A. B.; ALVES, A. U.; RIBEIRO CORREIA, M. A. Boron Foliar Application in Nutrition and Yield of Beet and Tomato. Journal of Plant Nutrition, v. 38, n. 10, p. 1573-1579, 2015. https://doi.org/10.1080/01904167.2015.1043373

HAJIBOLAND, R.; HAJIBOLAND, R., BAHRAMI-RAD, S., BASTANI, S., TOLRÀ, R., POSCHENRIEDER, C. Boron re-translocation in tea (Camellia sinensis (L.) O. Kuntze) plants. Acta Physiologiae Plantarum, v. 35, n. 8, p. 2373-2381, 2013. https://doi.org/10.1007/s11738-013-1272-3

HOAGLAND, D. R.; ARNON, D. I. The water-culture method for growing plants without soil. Circular. California Agricultural Experiment Station, v. 347, n. 2, 1950.

HU, W.; COOMER, T. D.; LOKA, D. A.; OOSTERHUIS, D. M.; ZHOU, Z. Potassium deficiency affects the carbon-nitrogen balance in cotton leaves. Plant Physiology and Biochemistry, v. 115, p. 408-417, 2017. https://doi.org/10.1016/j.plaphy.2017.04.005

ISLAM, M. Z., MELE, M. A.; BAEK, J. P.; KANG, H. M. Cherry tomato qualities affected by foliar spraying with boron and calcium. Horticulture, Environment, and Biotechnology, v. 57, n. 1, p. 46-52, 2, 2016. https://doi.org/10.1007/s13580-016-0097-6

ISLAM, M. Z.; MELE, M. A.; KI-YOUNG, C. H. O. I.; HO-MIN, K. A. N. G. The effect of silicon and boron foliar application on the quality and shelf life of cherry tomatoes. Zemdirbyste-Agriculture, v. 105, n. 2, p. 159-164, 2018. https://doi.org/10.13080/z-a.2018.105.020

KELLER, M.; SHRESTHA, P. M. Solute accumulation differs in the vacuoles and apoplast of ripening grape berries. Planta, v. 239, n. 3, p. 633-642, 2014. https://doi.org/10.1007/s00425-013-2004-z

LEAUNGTHITIKANCHANA, S.; FUJIBE, T.; TANAKA, M.; WANG, S.; SOTTA, N.; TAKANO, J.; FUJIWARA, T. Differential Expression of Three BOR1 Genes Corresponding to Different Genomes in Response to Boron Conditions in Hexaploid Wheat (Triticum aestivum L.). Plant and Cell Physiology, v. 54, n. 7, p. 1056-1063, 2013. https://doi.org/10.1093/pcp/pct059

MALAVOLTA, E. Manual de nutrição mineral de plantas. Agronômica Ceres, 2006.

MINCHIN, P. E. H.; THORP, T. G.; BOLDINGH, H. L.; GOULD, N.; COONEY, J. M.; NEGM, F. B.; ... BROWN, P. A possible mechanism for phloem transport of boron in 'Hass' avocado (Persea americana Mill.) trees. The Journal of Horticultural Science and Biotechnology, v. 87, n. 1, p. 23-28, 2012. https://doi.org/10.1080/14620316.2012.11512825

PÉK, Z.; SZUVANDZSIEV, P.; NEMÉNYI, A.; HELYES, L. Effect of season and irrigation on yield parameters and soluble solids content of processing cherry tomato. XIII International Symposium on Processing Tomato, v. 1081, n. 1, p. 197-202, 2014. https://doi.org/10.17660/ActaHortic.2015.1081.24

PEOPLES, T. R.; KOCH, D. W. Role of Potassium in Carbon Dioxide Assimilation in Medicago sativa L. Plant physiology, v. 63, n. 5, p. 878-81, 1979. https://doi.org/10.1104/pp.63.5.878 
REID, R. Understanding the boron transport network in plants. Plant Soil, v. 2014, n. 385, p. 1-13, 2014. https://doi.org/10.1007/s11104-014-2149-y

SAMET, H.; CIKILI, Y.; DURSUN, S. The role of potassium in alleviating boron toxicity and combined effects on nutrient contents in pepper (Capsicum annuиm L.). Agricultural AcademyBulgarian Journal of Agricultural Science, v. 21, n. 1, p. 64-70, 2015.

SANTIAGO, E. J. P.; OLIVEIRA, G. M.; RAMOS, M. D. M. V. B.; CARVALHO ROCHA, R.; PEREIRA, A. V. A. Características de rendimento de tomate cereja cultivado com e sem tela de sombreamento e diferentes lâminas de irrigação. Pesquisa agropecuária tropical, v. 48, n. 4, p. 374-381, 2018. 10.1590/198340632018v4853064

SARAFI, E.; SIOMOS, A.; TSOUVALTZIS, P.; THERIOS, I.; CHATZISSAVVIDIS, C. The influence of Boron on pepper plants nutritional status and nutrient efficiency. Journal of soil science and plant nutrition, v. 18, n. 3, p. 653-667, 2018. http://dx.doi.org/10.4067/S0718-95162018005001903

SILVA, F. C. D. S. Manual de análises químicas de solos, plantas e fertilizantes. Rio de Janeiro: EMBRAPA SOLOS, 2009.

SOUZA, J. A.; CANESIN, R. C. F. S.; BUZETTI, S. Mobilidade de boro em mudas de pessegueiro. Revista Brasileira de Fruticultura, v. 34, n. 3, p. 930-935, 2012. http://dx.doi.org/10.1590/S010029452012000300036

TAIZ, L.; ZEIGER, E.; MØLLER, I. M.; MURPHY, A. Fisiologia e desenvolvimento vegetal. Artmed Editora, 2017.

TANAKA, M.; FUJIWARA, T. Physiological roles and transport mechanisms of boron: perspectives from plants. European Journal of Physiology, v. 456, n. 4, p. 671-677, 2008. https://doi.org/10.1007/s00424-0070370-8

TARIQ, M.; MOTT, C. J. B. Effect of boron supply on the uptake of micronutrients by radish (Raphanus sativus L.). Journal of Agricultural and Biological Science. v. 1, n. 2, p. 1-8, 2006. https://pdfs.semanticscholar.org/c91f/3a71f08c5b7e9b7ed82c3dc6b60e15ba6e3e.pdf

VAN GOOR, B. J.; LUNE, P. Redistribution of potassium, boron, iron, magnesium and calcium in apple trees determined by an indirect method. Physiologia Plantarum, v. 48, n. 1, p. 21-26, 1980.

https://doi.org/10.1111/j.1399-3054.1980.tb03213.x

WILL, S.; EICHERT, T.; FERNÁNDEZ, V.; MÖHRING, J.; MÜLLER, T.; RÖMHELD, V. Absorption and mobility of foliar-applied boron in soybean as affected by plant boron status and application as a polyol complex. Plant and Soil, v. 344, n. 1-2, p. 283-293, 2011. https://doi.org/10.1007/s11104-011-0746-6 